\title{
Review Article: "A Hungarian Refugee in England and Holland." Pogany, George. 2012. When Even the Poets Were Silent: The Life of a Jewish Hungarian Holocaust Survivor under Nazism and Communism. Afterward by Istvan Pogany. Kenilworth, UK: Brandram, Imprint of Takaway Publishing. 263 pp.; Pogany, George. 2014. Where Is My Home? A Hungarian Refugee in England and Holland. Lexington KY: CreateSpace. 209 pp. Illus.
}

\section{Ruth G. Biro}

\begin{abstract}
The personal experiences of individuals who lived through the catastrophes of World War II, the Holocaust and the 1956 Hungarian Revolution have been told in many recent memoirs, greatly expanding our understanding of these historical events. In addition to the experiences of the narrators, the fate of their family members, friends, colleagues and entire communities who were all impacted by these events are also illuminated in these accounts. The two memoirs by George Pogany (b. 1928) cover his life since the early 1930s in Hungary, the Holocaust, communism, his escape to the West in 1956, his settlement in England, resettlement in Holland and his years as an international management consultant in several countries. Few memoirs transmit so vigorously the sweep, resiliency, and duration of the author's life and reflections as in Pogany's exceptionally detailed and insightful twofold memoir.
\end{abstract}

Keywords: Memoir, life writing, Hungarian Jews, World War II, Holocaust, communism, the 1956 Hungarian Revolution, expatriate experiences, émigré authors, international management training

Biography: Ruth G. Biro holds a B.A. in Political Science from Chatham College, a Master's degree in Library Science and a Ph.D. from the University of Pittsburgh. She is presently retired from the faculty at Duquesne University. Dr. Biro received two certificates on Holocaust Studies from Yad Vashem, Jerusalem, where she conducted research in the Department of the Righteous among the Nations and authored a paper on Raoul Wallenberg that is presently posted on the Yad Vashem Website. Her article entitled "Representations of Budapest in 1944-1945 in Holocaust Literature" was published in Comparative Central European Holocaust Studies (vol. edited by Louise O. Vasvári and Steven Tötösy de Zepetnek) by Purdue UP in 2009. Another article of hers, "Refuge, Resistance, and Rescue in Hungary in WWII: Religious and Cultural Interactions," was published in 2010 in Learn, Teach, Prevent: Holocaust Education in the 21st Century, edited by Carol Ritter and Wendy Wentworth. Dr. Biro is currently researching factors influencing prosocial behavior in the Hungarian Holocaust.

(cc) Br ULIS D. Sode 
Biro, Ruth G. "Review Article: "A Hungarian Refugee in England and Holland."

Pogany, George. 2012. When Even the Poets Were Silent: The Life of a Jewish Hungarian Holocaust Survivor under Nazism and Communism. Afterward by Istvan Pogany. Kenilworth, UK: Brandram, Imprint of Takaway Publishing. 263 pp.; Pogany, George. 2014. Where Is My Home? A Hungarian Refugee in England and Holland. Lexington KY: CreateSpace. 209 pp. Illus." Hungarian Cultural Studies. e-Journal of the American Hungarian Educators Association, Volume 9 (2016): http://ahea.pitt.edu DOI: 10.5195/ahea.2016.257

The two memoirs under review here, both written by Hungarian-born George Pogany (né György Sándor Platschek), take the reader on a journey from Pogany's birth in 1928, life in the 1930s in Orosháza in southeastern Hungary, to the nearby ghetto and on to the Strasshof socalled family labor camp in Austria, where together with his parents he spent ten months during the maelstrom of World War II and the Holocaust of Hungarian Jews. At liberation, seventeenyear old Pogany and his parents returned to Orosháza. Pogany attended the Budapest Péter Pázmány University, attained a degree in chemistry and worked under communism in two nationalized oil refineries near the capital city. During that period he married and in late 1956, with his wife and small son, he escaped to Austria, finally arriving in England in 1957. All these events of his early life are depicted in his first memoir entitled When Even the Poets Were Silent: A Jewish Hungarian Survivor under Nazism and Communism. Pogany continues his life story in England and Holland in his sequel memoir, Where Is My Home? A Hungarian Refugee in England and Holland, in which he covers his later life as an emigrant from his Hungarian homeland. In England, Pogany worked for Shell Oil until in 1969 he was transferred to Holland, where he held various positions with the company up to his retirement in 1986 at the age of fiftyeight. He then embarked on a twenty-two years long consulting and manager-training career that took him to many countries. In 1995 Pogany authored How to Be Happy in Holland: A Practical Guide, which presented a wealth of cultural information for expatriates, foreign diplomats and visiting business personnel, including comparisons of different countries. His two memoirs with compelling narrative on his life reveal his professional accomplishments, as well as his intercultural competence in three nations in a changing world.

In When Even the Poets Were Silent (2012), whose title alludes to Hungarian poet Miklós Radnóti's Sixth Eclogue of May 1944, Pogany sets out to write more than his own personal life story and seeks, in addition, to convey to his readers an inclusive picture of the people, places, times and occurrences of both the Nazi occupation and the communist era in his native Hungary. His experiences of the 1940s and 1950s portray the disruption of humanity and civility that led to the persecution and genocide that traumatized Pogany's youth and early adult life in the country and culture he loved. His first memoir is divided into eight major chapters, with a Foreword and an Epilogue as well as an Afterword, "The Jews of Hungary: From Emancipation to Genocide," written by his son, István Pogány (also spelled Istvan Pogany in some of his publications), presently a retired professor of International Law at the University of Warwick.

Chapter One, entitled "Orosháza," introduces to Pogany's readers his hometown of 28,000 people located in Békés County, a fertile, flat agricultural region in southeastern Hungary. In this chapter as throughout the entire twofold memoir Pogany presents vignettes from his life in detail, thus turning everyday or extraordinary scenes into almost folkloristic or ethnographic accounts. György Sándor Platschek (a surname he later changed to Pogány, presently written Pogany in both memoirs and throughout this review) was born into a middleclass, non-observant Jewish family in January 1928. His father, Lajos, a teacher of mathematics, was born in Nagyatád in western Hungary, and his paternal grandfather had grown up in the Hungarian town of Losonc (Lucenec, belonging to Czechoslovakia after World War I). His mother, Eleonora, a housewife, was born in Marmarossziget, a Transylvanian city lost to Romania in the 1920 Treaty of Trianon following WWI, where his maternal grandfather had 
Biro, Ruth G. "Review Article: "A Hungarian Refugee in England and Holland."

Pogany, George. 2012. When Even the Poets Were Silent: The Life of a Jewish Hungarian Holocaust Survivor under Nazism and Communism. Afterward by Istvan Pogany. Kenilworth, UK: Brandram, Imprint of Takaway Publishing. 263 pp.; Pogany, George. 2014. Where Is My Home? A Hungarian Refugee in England and Holland. Lexington KY: CreateSpace. 209 pp. Illus." Hungarian Cultural Studies. e-Journal of the American Hungarian Educators Association, Volume 9 (2016): http://ahea.pitt.edu DOI: 10.5195/ahea.2016.257

been a cobbler. In the interwar period many of Pogany's relatives spread across Hungary and to former Hungarian lands beyond the country's interwar borders so he never had the chance to meet them. The Jewish community of Orosháza in those years numbered some five hundred souls who only observed the Jewish holidays as part of their old traditions but not as their live ethos. There were no Orthodox Jews in town so the general appearance of the Orosháza Jews was much the same as that of their Christian neighbors. Pogany and other Jews of town considered themselves one hundred percent Hungarian or Jewish Hungarians, rather than Hungarian Jews. Dinner parties hosted by Pogany's parents featured Hungarian specialties such as plum brandy, chicken or mushroom soup, well-seasoned lamb roast, potatoes or tarhonya ['Hungarian egg pasta'], a vegetable in a roux with sour cream, and a dessert of krémes ['custardfilled puff pastry'] or dobostorta ['sponge layers with chocolate butter cream and caramel topping'], and coffee, all prepared with no concern for Jewish dietary laws. Each spring, like their Christian neighbors, the Platscheks bought a piglet that was later, when the cold season came, slaughtered by the butcher and prepared by Pogany's mother into sausage, bacon and ham, and then celebrated in the disznotor ['the Feast of the Dead Pig'] along with stuffed cabbage and Hungarian sour cream. Pogany describes in detail the Orosháza stores and their proprietors as well as the town's school, post office, bank, swimming pool, flour mill, the hotel and its residents. One of the two cinemas in town offered American films starred by Mickey Rooney, Judy Garland, and Shirley Temple, while the other featured Hungarian and German films. Chapter Two, "Persecution," relates Pogany's life and experiences since the start of WWII in 1939 to his liberation in 1945. Pogany recollects the separation of Jewish adolescent males from their gentile counterparts in Levente, the paramilitary youth movement that all boys were required to join. By June 1940 Hungary became an ally of Germany and Italy, the Axis Powers, and as such declared war on the Soviet Union on the Eastern Front. The rate of Hungarian military war casualties was extremely high and thousands were taken prisoners by the Soviets. Jewish men were conscripted into munkaszolgálat ['labor service'] and many more restrictive laws were being passed against Jews, excluding them from specified employments, public and cultural positions, and placing quotas on their admission to universities. At the time of the Nazi occupation of Hungary on March 19, 1944 Pogany was sixteen years old and one of five Jewish students in a class of thirty-two in his gimnázium.

Pogany's older brother, István, was studying mathematics and physics at Szeged and, shortly after receiving his diploma, was called to serve in the labor service. Orosháza's Jews, excluding men aged eighteen to forty-five serving in the labor service, were now moved to the Orosháza ghetto located in a wood-processing plant once owned by a Jewish family. Pogany's father had hidden his gold pocket-watch chain in a jar and buried it under a pear tree in their garden before moving to the ghetto and barely escaped capture by the csendörség, the civil guards of the Hungarian Ministry of the Interior, who interrogated the ghetto internees about valuables they may have hidden in their homes and then raided those homes. When the ghetto inhabitants were to be moved out of Orosháza, all were required to surrender their pens and pencils in order to make their communication with the outside world more difficult. Luckily, Pogany's silver-plated self-propelling pencil had been carefully placed on top of a beam in the ghetto and thus hidden from view. As in all ghettos, midwives searched women to ensure they 
Biro, Ruth G. "Review Article: "A Hungarian Refugee in England and Holland."

Pogany, George. 2012. When Even the Poets Were Silent: The Life of a Jewish Hungarian Holocaust Survivor under Nazism and Communism. Afterward by Istvan Pogany. Kenilworth, UK: Brandram, Imprint of Takaway Publishing. 263 pp.; Pogany, George. 2014. Where Is My Home? A Hungarian Refugee in England and Holland. Lexington KY: CreateSpace. 209 pp. Illus." Hungarian Cultural Studies. e-Journal of the American Hungarian Educators Association, Volume 9 (2016): http://ahea.pitt.edu DOI: 10.5195/ahea.2016.257

have hidden nothing in their body cavities. At the railway station about five hundred detainees had to board trains bound for Békéscsaba, from where they were taken to a brick factory in Debrecen. Many of the deported Jews now found themselves expressing their worries and prayers in Hungarian since most knew no Hebrew or formal Jewish prayers. Instead, their time was spent in parlor games and in reciting poems by Petőfi, Arany, and Ady until they grew tired. The train they thought was going north now seemed to be heading westward to Vienna. The Platscheks and the other internees disembarked at Strasshof, a village on the eastern outskirts of Vienna, where men and women were separated and led into the barracks of a concentration camp and where they were given showers. After a forced march, part of the Orosháza group arrived at a labor camp called No.4 Hafenzufahrtsstraße, on the southern bank of the Danube, where they would remain for the remaining ten months of the war.

The prisoners from Orosháza worked for a private firm of railway-line builders known as Bauunternehmung Fioravante Spiller \& Sohn. Their barracks held about eighty-five people and housed entire families together as this was a kind of a family camp. The bunks nearby the Platscheks were all occupied by former Orosháza residents they knew well. Everyone except children, the very old and the sick worked six days a week. On the free day they spent most of the time talking about the good old days, fine foods and simple pleasures of the time before the deportation to camp. The internees suffered from frequent Allied Forces air raids, cold winter weather and starvation. Travel to work sites was mostly on public transportation, with an occasional truck transport. Trams would cease running during air raids so work gangs wearing yellow stars and speaking various languages would have to make their way by foot through the unfamiliar city. Pogany experienced some one hundred and fifty terrifying air raids by the British Air Force and U.S. bombers. Although they had no radios or newspapers, they did learn from passing Hungarian sailors about D-Day, an event that boosted their morale, and on one occasion Pogany actually encountered a man of dark complexion for the first time in his life, presumably a prisoner of war from D-Day or a survivor of a crash landing.

In Chapter Three, titled "Liberation," Pogany states that during the entire stay of his group of forced laborers in Austria none of them knew about the death camps of the Nazi regime. Hungarian merchant sailors told the group about the Russian advance into Hungary and that the Soviets were on the approach to Austria. Feeling bolder than before at hearing such news, some of the Orosháza group ventured outside the camp to wait for the Russians. After two or three days, with fighting all around them, the Russians began arriving a few at a time. A Russian soldier showed up and said his commandant had lost his watch and needed a replacement; Pogany's father offered his pocket watch, but the commandant wanted a wristwatch, so Pogany offered his. As if on a trophy hunt, the Russians collected more and more wrist watches and some of them sported watches decorating both their forearms up to the elbow. The Orosháza Jews now started walking toward the Hungarian border. They now realized that their excruciating journey to Vienna a few months beforehand had actually saved them from the Arrow Cross terror of October 1944, but what would Pogany, now aged seventeen, and his parents face upon their return home? For himself, despite his recent suffering by his Hungarian countrymen, Pogany still felt that his future lay in the hopefully newly freed Hungary. On a train from Györ to Budapest, his family travelled together with residents of the capital city, refugees, 
Biro, Ruth G. "Review Article: "A Hungarian Refugee in England and Holland."

Pogany, George. 2012. When Even the Poets Were Silent: The Life of a Jewish Hungarian Holocaust Survivor under Nazism and Communism. Afterward by Istvan Pogany. Kenilworth, UK: Brandram, Imprint of Takaway Publishing. 263 pp.; Pogany, George. 2014. Where Is My Home? A Hungarian Refugee in England and Holland. Lexington KY: CreateSpace. 209 pp. Illus." Hungarian Cultural Studies. e-Journal of the American Hungarian Educators Association, Volume 9 (2016): http://ahea.pitt.edu DOI: 10.5195/ahea.2016.257

war volunteers and ex-soldiers. This was the first time Pogany saw Budapest and now he was gazing at the once magnificent city presently damaged and destroyed. The family later learned that their older son István had survived the war in labor service only to be captured, as he was returning to Orosháza, by the Russians and had been sent to slave labor in the Soviet Union, where, according to eyewitnesses, he died of starvation. The Jewish community in Budapest supplied the Platschek family with emergency money and they continued on their homeward journey.

Arriving in Orosháza, the Platscheks found most of their possessions untouched and Pogany was even able to retrieve his precious self-propelling pencil from the ghetto beam. He never found his violin, but his accordion was later returned to him, and his father dug up his gold chain from under the pear tree. Neighbors came to greet them and brought them food, which was remarkably different than the hostile welcoming of many other returning Jews by their past socalled good neighbors. The family's missing bed linens and the goose down quilt were returned after two days and Pogany's mother thanked the neighbors for their safekeeping. Orosháza has changed considerably in the year of the deportation of its Jews to forced labor in Austria: shops now sold inferior goods; the Alföld Hotel no longer served its famous steaks; the Sternbergs, who made eiderdown quilts, left to Israel; no one promenaded any longer on Kossuth utca ['Street'] on Sunday morning; the Platschek family no longer held dinner parties and instead searched or waited for its lost relatives. More than half of Orosháza's Jews did return, which was extremely exceptional since these Jews were luckily sent to an Austrian work camp for entire families rather than to Auschwitz, but across Hungary almost half a million Jews had been murdered in the Holocaust. Four of the five Jewish students in Pogany's former class, including himself, returned. Pogany, now more conscious of his Jewish identity, joined the Hashomer Hatsair ['Young Guard'] movement, a socialist-Zionist youth organization, and hoped to go to Israel. As a compromise to his parents he agreed to attend university in Hungary and leave for Israel only once he had his degree in hand. Then, following a recruiting campaign aimed at young people in his hometown, Pogany joined the Communist Party. He soon passed his entrance exam in Hungarian, history, Latin, German, mathematics and physics, and he was accepted for university studies in chemistry.

In Chapter four, entitled "University," Pogany describes his chemistry studies at Péter Pázmány University in Budapest. The State-funded education was free and the American-Jewish Joint Distribution Committee provided Pogany with rent-free lodging in a student hostel. Hungarian textbooks were in short supply, food in the pockmarked capital city was scarce and choices were restricted. Families sent their children parcels from home and the Danish Red Cross supplied them with margarine and coffee beans; yet the students often lived on bread fried in margarine. During the winter of his first year at the university Pogany met Vera Faragó, who came from a poor Jewish family in Budapest. In early 1945 she had been called to work in a women's labor camp but managed to escape by hanging back and pretending to tie her shoelaces, a trick that sometimes saved one's life but more often brought destruction on the person venturing such ploys. The next day the Arrow Cross rounded up Jewish men for labor service, including Vera's father, who later disappeared and was never seen again. The caretaker of the family's previous apartment offered to shelter Vera, her brother and their mother in an empty flat, 
Biro, Ruth G. "Review Article: "A Hungarian Refugee in England and Holland."

Pogany, George. 2012. When Even the Poets Were Silent: The Life of a Jewish Hungarian Holocaust Survivor under Nazism and Communism. Afterward by Istvan Pogany. Kenilworth, UK: Brandram, Imprint of Takaway Publishing. 263 pp.; Pogany, George. 2014. Where Is My Home? A Hungarian Refugee in England and Holland. Lexington KY: CreateSpace. 209 pp. Illus." Hungarian Cultural Studies. e-Journal of the American Hungarian Educators Association, Volume 9 (2016): http://ahea.pitt.edu DOI: 10.5195/ahea.2016.257

and with false-identity papers secured by Vera's mother all three were able to survive to the end of the war. After the war, Vera's family received from the Save the Children Fund of Bath, England, a monthly food parcel of flour, sugar, rice and other bare necessities. The Soviet Army now replaced the Nazis and the Arrow Cross, only to loot the city, deport thousands to the gulag and rape women at will. Vera's brother Bertalan was detained by the Soviets but escaped. Pogany and Vera got engaged during his second year at university and married when he was twenty years of age. Following a civil and a religious ceremony, they held a simple reception consisting of savory pogácsa ['scone-like biscuit'] and homemade liqueurs. In 1950 Pogany graduated and began working as a chemist at a refinery in Almásfüzitő in North-Western Hungary that formerly belonged to the Vaccuum Oil company, predecessor of the U.S. Mobil Oil Company. Pogany found that his attachment to the Zionist movement had weakened and he now envisioned staying in his Hungarian homeland and forging his life there. Ready to be assimilated, he changed his Jewish surname Platschek to the Hungarian sounding name of Pogány ['pagan'].

In Chapter Five, "Almásfüzitő," Pogany details the country's transformation to communism. People now greet one another using the communist term elvtárs ['comrade']. Large farming estates are confiscated by the state and the land is gradually changed into State-owned agricultural facilities. Small landholders see their plots turned over to large collective farms where prescribed production targets are instituted and food shortages again, as in the war, appear. Many goods and produce are sent from Hungary to the Soviet Union to compensate for its war damages and support its industrialization projects. Yet, the Hungarian Communist Party blames the shortages on the kuláks ['wealthy peasants'] instead of blaming the system and publishes photographs of some kuláks with sacks of potatoes that police allegedly found in their homes. After interrogation the kulák potatoes are confiscated, but the shortages persist. To ensure ideological correctness, the practice of publically expressing self-criticism is adopted, even if the confession is invented, forced on the person delivering it, or embarrassingly foolish. For many citizens the simple pleasure of strolling by the Danube or reading a book becomes a welcome refuge from the heavy-handedness and menace of the system. Later, in the early 1950s, Pogany is transferred to Vegyterv ['Chemical Planning'] at Budapest, the central design office for the chemical industry. Unlike his colleagues in Almásfüzitő, the Vegyterv staff is highly qualified. In addition, quite a few women engineers and scientists are employed in the workplace, the result of Marxist doctrine espousing sexual equality. In 1952 Pogany is called to military service. Formerly exempt from the draft as a university student, his call did not come earlier. Serving in the artillery, he functions as a spotter, directing fire. Vera is now pregnant and they soon welcome a son, naming him István after Pogany's older brother.

In chapter seven, "The Thaw," Pogany describes how with time he noted that under the Khrushchev regime life began to slowly improve. The gulag is dismantled in Russia and Hungary, and the lucky survivors return home, including a colleague from Vegyterv, who returns after years of working in a stone quarry. Although people around him ask him many questions, still fearful of the authorities, this man would only say very little about his experiences in the gulag. Books are cheap and publication depends on the suitability of the political message in them. New and second-hand bookstores open and volumes are sold at city stalls. Cinemas in the city show politically acceptable entertainment and Soviet propaganda. The opera and theaters 
Biro, Ruth G. "Review Article: "A Hungarian Refugee in England and Holland."

Pogany, George. 2012. When Even the Poets Were Silent: The Life of a Jewish Hungarian Holocaust Survivor under Nazism and Communism. Afterward by Istvan Pogany. Kenilworth, UK: Brandram, Imprint of Takaway Publishing. 263 pp.; Pogany, George. 2014. Where Is My Home? A Hungarian Refugee in England and Holland. Lexington KY: CreateSpace. 209 pp. Illus.” Hungarian Cultural Studies. e-Journal of the American Hungarian Educators Association, Volume 9 (2016): http://ahea.pitt.edu DOI: 10.5195/ahea.2016.257

offer cheap yet excellent entertainment. Beauty salons operate on shifts to provide manicures and pedicures to women wishing to look their best. Pogany's parents, born in the days of the AustroHungarian Empire, have been through so much that communism fails to ruin their daily lives.

In the summer of 1956 ruler Rákosi was removed from power and replaced by Ernő Gerö, another hard line communist leader. On October 2, 1956 a student demonstration outside the radio station turned violent and the guards opened fire on the crowd. Soldiers joined the group and the next day, amidst fighting, chaos and Soviet tanks, Gerö fled to the Soviet Union and was immediately replaced by Imre Nagy, whom the demonstrators supported. Nagy became head of the new government and Hungary was free for a short time. During this time government offices were broken into by people searching for personal information about themselves and others. Pogany's records, for example, revealed that their major crime was that the family received parcels of coffee, cocoa, and nylons from an aunt in New York. On November 4, the Soviet Army squashed the Hungarian Revolution of 1956 and in less than a week the uprising was over with two thousand Hungarian victims perished. While all this was going on, Pogany was on a business trip to Romania with a few chemical engineers. After learning of the uprising they wished to return home but the Romanian authorities delayed processing their exit visas. On November 3, Pogany and his colleagues got their exit visas and proceeded to Hungary, where Pogany now realized he had had enough of communism and knew he must leave Hungary to build a better life for himself and his family.

In Chapter Eight, "Freedom," we learn that Pogany, Vera, and István were among the last of the 200,000 Hungarians who left the country. They boarded a train on December 15, 1956 from Budapest to Vienna with tickets to Mosonmagyaróvár, taking no valuables, address books, or passports with them. They also left behind them precious photographs, letters, important documents, and Pogany's chemistry diploma. To prevent suspicion, all three wore old clothes and packed a few sandwiches. In their six-seat compartment were two ladies and a uniformed railway man. When one of the ladies asked István where he was going, he responded they were on their way to visit his grandmother in Orosháza -- clearly in the wrong direction, as everyone knew. With their cover blown, Pogany was met in the corridor by the railway man, who winked in recognition of their plan, and offered to help him. Pogany adopted an alternative plan offered him by the railway man. At Levél, one stop after Mosonmagyaróvár, the railway man led them to the signalman's hut, where they remained hidden and undetected by security soldiers. He then led them to his house, where passing Russian soldiers asked for water but did not enter the premises, thereby leaving Pogany and others undetected. The next day a whole group assembled for escape to Austria comprising of eight adults, a twelve-year-old boy and four-year-old István, who was often carried by others on the cold night over a zigzag route.

In Austria, the Pogany family is taken by car to the Red Cross refugee camp at Nickelsdorf, where the children are given hot chocolate and the adults are offered chicken soup. From the transit camp they are sent to a Red Cross camp at Modling, near Vienna, and less than twenty kilometers from Pogany's past labor camp at Hafenzufahrtsstraße. Soon the Poganys are sent to the nearby castle of Schloss Liechtenstein, where families are housed, given pocket money, and offered manual work with pay. Pogany is appointed team leader and makes many excursions to Vienna, where he attempts to secure documentation of his time in the labor camp 
Biro, Ruth G. "Review Article: "A Hungarian Refugee in England and Holland."

Pogany, George. 2012. When Even the Poets Were Silent: The Life of a Jewish Hungarian Holocaust Survivor under Nazism and Communism. Afterward by Istvan Pogany. Kenilworth, UK: Brandram, Imprint of Takaway Publishing. 263 pp.; Pogany, George. 2014. Where Is My Home? A Hungarian Refugee in England and Holland. Lexington KY: CreateSpace. 209 pp. Illus." Hungarian Cultural Studies. e-Journal of the American Hungarian Educators Association, Volume 9 (2016): http://ahea.pitt.edu DOI: 10.5195/ahea.2016.257

working with Siller \& Sohn, with no result even though the firm is still operating. From Schloss Liechtenstein the refugees depart to South America, the U.S., Israel, and other locales around the world; Pogany chooses England. Met by Vera's relatives Feri and Gyuri, who already lived there, they all enjoy coffee and fruitcake together before the Poganys are sent north to Staffordshire to the Royal Air Force base of Hednesford, where during the war repairs were made to airplanes carrying Allied bombs that helped liberate Europe from the Nazis. In February 1957 Pogany has high hopes that this foreign country would become his home for the rest of his life.

In the book's Epilogue Pogany reports on his and Vera's first visit back to Hungary in 1973, sixteen years after they left. István, now aged twenty, does not accompany them because they fear he might be recruited into the Hungarian army. They travel by car across Europe. Near Hungary Pogany happens to turn on Kossuth Radio not far from where he and his parents returned from the labor camp back in 1945 and where in 1956 he escaped to Austria with his wife and small son. The tower at the Hungarian border is guarded by a Soviet soldier with a machine gun at the ready. The couple continues to Budapest hoping to find the little place where they bought lángos years before, but it is gone. In the 1990s Pogany visits Hungary again and revisits his hometown of Orosháza, this time traveling by train from Szeged, where he is then teaching managers to work in a market economy. In Orosháza he discovers that his family home and other houses on Ord utca disappeared and were replaced by ugly apartment buildings. His old school is gone, too, and the town synagogue stands in a decrepit state. Pogany visits his father's neglected grave in the Jewish cemetery and leaves Orosháza for the last time.

Pogany's next volume, Where Is My Home?, continues the family's story since after they left Hungary in 1956, spent two months in refugee camps in Austria, arrived in England in 1957, and then moved to Holland in 1969 and remained there. At the age of eighty, Pogany began to write his memoirs covering his twenty eight years in Hungary, his almost thirty years with Shell Oil in England and Holland, his retirement at age fifty eight and his experiences training managers for twenty-two years in eight countries and in three different languages.

The first four chapters in Where Is My Home? describe Pogany's life as a refugee and naturalized citizen of England. In order to prepare himself for a new life in a new country Pogany seeks the assistance of his wife's uncle Feri to prepare his curriculum vitae and memorize its contents. In a very short time he has five interviews, the last with Shell, for an opening in Manchester. Vera has jobs in various companies, including one at Kellogg, the American company famous for its cornflakes, in Manchester and at the Coca-Cola bottling plant in Oxford, where she works as the director's secretary. In these chapters Pogany delineates his adjustment to the new culture, his work experiences, his obtaining of a Ph.D. at Oxford University, and his last years in England until his transfer to Holland on August 15, 1969. Here again, as he did in his descriptions of his early life in Orosháza, he relates in detail the many cultural differences he encountered in England compared to Hungary, including body language and food and drink practices such as having English tea with milk, sherry drinks, trifle dessert, baked beans on toast, crusts cut off bread destined for sandwiches, cold houses, British drizzle, pub crawls, formal dress on weekdays and casual attire on weekends, and many other features he will later discuss in his How to be Happy in Holland guide. 
Biro, Ruth G. "Review Article: "A Hungarian Refugee in England and Holland."

Pogany, George. 2012. When Even the Poets Were Silent: The Life of a Jewish Hungarian Holocaust Survivor under Nazism and Communism. Afterward by Istvan Pogany. Kenilworth, UK: Brandram, Imprint of Takaway Publishing. 263 pp.; Pogany, George. 2014. Where Is My Home? A Hungarian Refugee in England and Holland. Lexington KY: CreateSpace. 209 pp. Illus." Hungarian Cultural Studies. e-Journal of the American Hungarian Educators Association, Volume 9 (2016): http://ahea.pitt.edu DOI: 10.5195/ahea.2016.257

In these later decades both Pogany's mother and his mother-in-law left Hungary and came to live in England. His son István became known as Stephen, yet retained the ability to converse, read, and write in Hungarian. At Oxford, George Pogany interacts with internationals from many countries, including Pakistan, Egypt, Ireland, Russia, America and more; and in June 1967 he earns his doctorate on the subject of polymer physics. Three more chapters in Where Is My Home? describe his career, social life, and experiences in Holland. In 1969 Pogany accepts an offer to work at the head office of Shell in the Hague for a two-year stint. In The Hague the Poganys once again live as expatriates in a new county, experiencing culture shock and learning yet another language. Both Pogany and Vera attend a language lab at Shell where Pogany now makes notes about the differences between his life in Holland compared to both England and Hungary. The English put vinegar on their chips while the Dutch and Belgians eat French fries with mayonnaise. Dutch coffee is stronger than English coffee, but both are weaker than the Hungarian variety. The national drink of Holland is buttermilk and a favorite dish is raw herring with chopped onion and pickled gherkins. Also, the Dutch eat sandwiches with fork and knife, thick pea-soup with black bread, and they drink genever ['Dutch gin'] before dinner. When Pogany offers visitors at his home Hungarian pálinka ['fruit brandy'], they are willing to try it but return to their own country's favorite. The Poganys find life in Holland more competitive than in England, with people pushing through the crowd and not observing the orderly queues renown in England. He notes that at first he and Vera put less effort into cultural integration in Holland than they might have done had they known they would be staying there for more than two years. Most of their friends are expatriates, too, and they speak mainly English. István attends an English school together with expatriates, diplomats, and business executives. After passing his A-Level exams, he decides on the field of international public law and attends the University of Edinburgh. Having retained their British nationality, the Poganys are considered foreigners in the Hague international community. While attending university, Pogany regards his experience with many internationals as valuable, partly because it teaches him that integration does not mean that one has to give up or desert one's identity when living elsewhere.

In the eighth chapter in Where Is My Home?, entitled "Training Managers," Pogany details how, after retirement and when no calls for consultation from Shell are forthcoming, he can still find suitable occupations. An organization invites him to present lectures to expatriates on the topic of "Know the Netherlands" and for several years he presents lectures on middle management, offering many courses per year in English or Dutch. Eventually that program closes and Pogany turns his attention to a course for technical managers entitled "Leading Technical Personnel," which runs for fifteen years. Responding to an advertisement for a parttime instruction job at an American university in Leiden, Pogany is initially assigned to an undergraduate evening course for working adults but later gets to teach the capstone M.B.A course entitled "Business Policies and Strategies." Pogany enjoys making his own decisions on the knowledge, experiences and perspectives he would share with managers and students, as well as the fact that Vera can accompany him on trips abroad. After twenty-two years of presenting in eight countries in three languages, he realizes his examples may be dated, the competition from other firms increases, and younger participants expect more entertainment with his advice. In his seventies, Pogany turns his attention to revising his pamphlet on Holland and turning it into the 
Biro, Ruth G. "Review Article: "A Hungarian Refugee in England and Holland."

Pogany, George. 2012. When Even the Poets Were Silent: The Life of a Jewish Hungarian Holocaust Survivor under Nazism and Communism. Afterward by Istvan Pogany. Kenilworth, UK: Brandram, Imprint of Takaway Publishing. 263 pp.; Pogany, George. 2014. Where Is My Home? A Hungarian Refugee in England and Holland. Lexington KY: CreateSpace. 209 pp. Illus." Hungarian Cultural Studies. e-Journal of the American Hungarian Educators Association, Volume 9 (2016): http://ahea.pitt.edu DOI: 10.5195/ahea.2016.257

book How to Be Happy in Holland, with illustrations by his uncle István Czegledi, which was published in Holland in 1995. In this book he states that his main message is that foreigners should integrate into the new environment in order to be happy, but need not fully assimilate or give up their previous identity. Vera and George Pogany celebrate their fiftieth anniversary with relatives from abroad, Dutch friends, and couples from England. For their sixtieth anniversary the mayor of Naarden sends them flowers and the Queen of the Netherlands offers a congratulatory letter. George and Vera celebrate the occasion by snorkeling in Egypt. After retirement they buy a motorboat so that each spring they can sail around the waterways of Holland for several weeks.

The ninth and last chapter, "Visiting Hungary," describes Pogany's trips to his Hungarian homeland. In 1945, after the war, Pogany thought he would remain in Hungary for the rest of his life. Later, in 1973, after sixteen years abroad as of the Hungarian Revolution, he realized he would never return to live in Hungary but rather remain in Holland as a British citizen. A few years later the Poganys make another trip to Hungary and observe some of the changes under communism. Mainly, they discover, there is ever more favoritism and corruption in their past country. East-German Trabant automobiles emit much pollution, food is plentiful but the shops are filled with goods of inferior quality, and a black market economy prevails within the planned national economy. Authorities find it hard to understand the free movement of people in Europe and ask the Pogany couple why, if they live in Holland, they do not carry Dutch passports but British ones. Hungarians at that time vacation in resorts on Lake Balaton or in Sochi, the Russian holiday destination on the Black Sea, and they can also vacation in North Korea. Noting the needs of the Hungarian job market at the time, Pogany sets up a company named International Scientific Services to deal with Hungarian software concerning analysis of spent catalysts such as platinum, but in 1989 the new freedom in Hungary presents difficulties in changing the country's economy from a planned to a market economy.

In the meantime, Pogany's son István becomes a professor of international law at Warwick University, UK, specializing in human rights in Eastern and Central Europe. When István begins visiting Hungary for his research, he purchases an apartment in Budapest where he would write and translate. For George Pogany, visiting Hungary once more in 2002, his past homeland has become a strange place because he has gotten used to life in the West. He can no longer laugh at the Hungarian jokes because he lacks reference points. Some Hungarians observe that the Hungarian spoken by Vera and him sounds foreign, which strengthens the couple's feeling that they no longer belong to the land of their birth. In the Epilogue Pogany reveals that outside Hungary they are often asked if they wish to permanently return to Hungary now that it has become a democracy and they always answer they would not. As a Hungarian patriot of Jewish origin born in Hungary, deported from his nation by the Nazis and the Hungarian fascists, then subjected to Soviet oppression in his homeland, Pogany now enjoys British nationality, resides in Holland, yet feels a foreigner. He speaks three languages, none absolutely perfectly and he still mixes up words and expressions. Where is my home? Pogany asks, and his answers is: "where you happen to live, where your bed is" ( 208). 
Biro, Ruth G. "Review Article: "A Hungarian Refugee in England and Holland."

Pogany, George. 2012. When Even the Poets Were Silent: The Life of a Jewish Hungarian Holocaust Survivor under Nazism and Communism. Afterward by Istvan Pogany. Kenilworth, UK: Brandram, Imprint of Takaway Publishing. 263 pp.; Pogany, George. 2014. Where Is My Home? A Hungarian Refugee in England and Holland. Lexington KY: CreateSpace. 209 pp. Illus." Hungarian Cultural Studies. e-Journal of the American Hungarian Educators Association, Volume 9 (2016): http://ahea.pitt.edu DOI: 10.5195/ahea.2016.257

Pogany's book When Even the Poets Were Silent was reviewed in 2013 by Hungarian Holocaust survivor Ladislaus Löb, a former lucky passenger of the wartime Kasztner train to Switzerland and a professor emeritus of Sussex University, as well as by Mona Tombol in the Vienna Book Review the same year. Both reviewers are well acquainted with the settings and situations in Europe that Pogany describes. From my reading of his books as an American reviewer, both of his books would benefit if maps of locales in Hungary and Austria and routings to England and Holland were included to assist readers with Pogany's journey to Strasshof in the Holocaust, work experience near Budapest, emigration from Hungary, travel to England, and relocation to Holland. Because Pogany's life story is told from memory, he does not cite scholarly references; yet these citations are provided by István Pogany in his Afterward to the first book. This first book, When Even the Poets Were Silent, has no illustrations, presumably because family and other relevant photographs were lost in the war or not recovered prior to the Poganys' departure from Hungary in 1956. The second book, Where Is My Home?, by contrast, contains many photographs, greatly enhancing the impact of the text. Pogany's two moving and detailed memoirs offer a unique view of his years as a young Hungarian patriot, a labor camp survivor, a disillusioned professional chemist working under communism, a refugee and expatriate in two countries, a successful career-man, an instructor of managing professions, and a traveler to many lands. One may aver that George Pogany's When Even the Poets Where Silent and Where Is My Home? may be among the last memoirs to cover such a lengthy and eventful time span of a person living through most of the twentieth century in several European countries, of which Hungary is the first and thus of paramount importance despite the author's many decades of a fulfilled and rewarding life away from his homeland.

\section{Works Cited}

Biro, Ruth G. and Christina Levicky. 2008. "Literature for an Interdisciplinary Holocaust Course: Books on the Hungarian Holocaust for Comparative Cultural Study, Teaching the Holocaust in Catholic Schools. Ed. Kathleen McSharry. Greensburg, PA: National Catholic Center for Holocaust Education and Seton Hill University: 101-110.

Löb, Ladislaus. 2013. "Review: When Even the Poets Were Silent: A Jewish Hungarian Holocaust Survivor under Nazism and Communism. "East European Jewish Affairs 43.2: 220-223.

Pogany, George. 1995. How to Be Happy in Holland: A Practical Guide. Hoevelaken, Netherlands: Uitgeverij Verba.

Tombol, Mona. 2013. "When Even the Poets Were Silent." Vienna Book Review, May 20. https://www.viennareview.net/Vienna-review-book-reviews/breaking-the-silence2BookReview-; WhenEvenThePoetsWereSilent 